\title{
Surgical resection of pleomorphic adenoma
}

Ricardo Eugenio Varela Ayres de Melo ${ }^{a}$, Marcela Côrte Real Fernandes ${ }^{\mathrm{b}}$, Rodrigo Henrique Mello Varela Ayres de Meloc Milena Mello Varela Ayres de Melo Pinheiro ${ }^{d}$, Victor Leonardo Mello Varela Ayres de Melo ${ }^{e}$, Camilla Siqueira de Aguiar ${ }^{f}$

\begin{abstract}
OBJECTIVE: The Pleomorphic Adenoma is the most common among benign neoplasm derived from salivary glands and it might suggest malignancy when there is some sort of fast growth, pain, facial nerve involvement and cervical adenopathy. Its onset occurs between 40 and 60 years old and prevails on the female gender. Salivary glands tumor diagnosis depends on a precise pathological diagnosis as well as non-invasive examinations, which include ultrasonography sialography, computed tomography and magnetic resonance imaging. The most recommended surgical treatment is the complete lesion excision, indispensable to avoid possible recurrence. Depending on the lesion situs, size, depth, and volume, the surgical technique choice for the pleomorphic adenoma may vary. The adenoma keeps developing if it is not completely removed. CASE DESCRIPTION: The present paper aims to describe a clinical case of a female melanodermic patient, aged 29 years old, who attended the MaxilloFacial Surgery and Traumatology Service of Federal University of Pernambuco complaining of an increased volume in the left submandibular region. The clinical examination revealed a well-delimited lesion in the left parotid area, presenting with a firm and painless consistency. The required ultrasonography image confirmed the initial diagnosis and the patient was referred to the surgical facility in order to undertake tumor resection with partial parotidectomy under general anesthesia.

CONCLUSION: The present study concludes that pleomorphic adenoma is a benign tumor with diverse characteristics and surgical technique choice depends on the lesion depth, as well as its extension and relation with the facial nerve.
\end{abstract}

Keywords: pleomorphic adenoma; oral surgery; salivary gland diseases.

\section{Ressecção cirúrgica do adenoma pleomórfico}

\section{RESUMO}

OBJETIVO: O adenoma pleomórfico é o mais comum entre as neoplasias benignas derivadas de glândulas salivares e pode sugerir malignidade quando há algum tipo de crescimento rápido, dor, comprometimento do nervo facial e adenopatia cervical. Seu início ocorre entre os 40 e os 60 anos e predomina no sexo feminino. 0 diagnóstico do tumor nas glândulas salivares depende de um diagnóstico patológico preciso e de exames não invasivos, que incluem ultrassonografia, sialografia, tomografia computadorizada e ressonância magnética. 0 tratamento cirúrgico mais recomendado é a excisão completa da lesão, indispensável para evitar uma possível recidiva. Dependendo do local da lesão, tamanho, profundidade e volume, a escolha da técnica cirúrgica para o adenoma pleomórfico pode variar. O adenoma continua se desenvolvendo se não for completamente removido. RELATO DO CASO: O presente artigo tem como objetivo descrever um caso clínico de uma paciente melanodérmica, do sexo feminino, com 29 anos de idade, que compareceu ao Serviço de Cirurgia e Traumatologia Maxilofacial da Universidade Federal de Pernambuco com queixa de aumento de volume na região submandibular esquerda. O exame clínico revelou lesão bem delimitada na região da parótida esquerda, apresentando consistência firme e indolor. A imagem ultrassonográfica confirmou o diagnóstico inicial e a paciente foi encaminhada ao centro cirúrgico para realizar a ressecção do tumor com parotidectomia parcial sob anestesia geral.

CONCLUSÃO: O presente estudo conclui que o adenoma pleomórfico é um tumor benigno com características diversas e a escolha da técnica cirúrgica depende da profundidade da lesão, bem como de sua extensão e relação com o nervo facial.

Palavras-chave: adenoma pleomórfico; cirurgia bucal; doenças das glândulas salivares.
${ }^{a}$ Coordinator of the Specialization Course in Maxillofacial Surgery and Traumatology of the Federal University of Pernambuco (UFPE), Recife, Brazi

Dental Surgeon, Recife, Brazil

General Surgeon, Physician, Recife, Brazil

${ }^{d}$ Physiotherapist, Trainee at the Maxillofacial Surgery and Traumatology Ambulatory of the Federal University of Pernambuco (UFPE), Recife, Brazil

e Undergraduate Dentistry student of Maurício de Nassau University, Trainee at the Ambulatory of Maxillofacial Surgery and Traumatology of the Federal University of Pernambuco (UFPE), Recife, Brazi

Undergraduate Dentistry student of the Federal University of Pernambuco (UFPE), Trainee at the Ambulatory of Maxillofacial Surgery and Traumatology of the Federal University of Pernambuco, Recife Brazil
Correspondence:
Ricardo Eugenio Varela Ayres de Melo revamelo@yahoo.com

Received: January 13, 2018 Accepted: January 15, 2019

Conflict of Interests: The authors state that there re no financial and personal conflicts of interest that could have inappropriately influenced their work.

Copyright: (C) 2018 de Melo et al.: licensee EDIPUCRS.

This work is licensed under a Creative Commons Attribution 4.0 International License. 


\section{INTRODUCTION}

Pleomorphic adenoma is the most common benign salivary neoplasm, accounting for $80 \%$ of such group. Most of these lesions are found in large salivary glands, mainly affecting the parotid gland [1]. About $8 \%$ of pleomorphic adenomas involve the minor salivary glands, mostly encompassing palatine ones, followed by the labial glands [2]. Pleomorphic adenoma occurs mostly in females and may appear at any age, although rarely in children, having its onset mainly between the fourth and sixth decades of life [3]. Clinically, a usual manifestation a pleomorphic adenoma is the presence of a solid, firm, lobulated and longlasting mobile mass with well-defined borders, painless in palpation [4]. Pleomorphic adenomas are usually discovered in routine physical examination as an asymptomatic mass, being symptomatic when they compress nerve-ending areas due to increases in volume, however as they present with slow progression, they usually reveal a $2-6 \mathrm{~cm}$ size [5]. Although the majority (95\%) of pleomorphic adenomas are benign, a small fraction may demonstrate aggressive onset such as pleomorphic ex-adenoma carcinoma. This can occur after several local recurrences and/or after radiotherapy [6]. Malignancy may arise in three forms: the adenoma expleomorphic carcinoma, carcinosarcoma and pleomorphic adenoma metastasis [7].

Jayaram; Patel; Santhanam (2015) [8] described the rare existence of a perineural involvement associated with a benign pleomorphic adenoma that mimicked a malignant process. Ultrasonography, sialography, computed tomography and magnetic resonance imaging (MRI) are used as complementary exams. MRI is considered the method of choice for the evaluation of pleomorphic adenomas since it allows their visualization in almost all cases. In addition, MRI is superior in soft tissue differentiation, deep tissue and facial nerve visualization [5]. The delimitation of the adenoma extent is best described by MRI, as it reveals the multinodular nature of the disease. MRI also facilitates the determination of the amount of residual parotid gland. When there is contrast administration, the lesions demonstrate slight improvement in their image. Nevertheless, MRI may also be inadequate for the identification of all nodules since in surgery other nodules are revealed rather than the only suspected ones. However, it is necessary to emphasize that the histopathological diagnosis of the adenoma is indispensable [9]. The pleomorphic adenoma of the salivary gland treatment is its complete excision, which provides both diagnostic and therapeutic effect. When discussing the procedure with the patient and the family, it is important to consider the risk of recurrence, which ranges from $0 \%$ to $13 \%$ [10]. Superficial or total parotidectomy involves the resection of a considerable amount of normal parotid tissue with dissection of the facial nerve, often resulting in facial nerve damage and facial nerve disfunction. The risks led surgeons to adopt less invasive surgical techniques, such as extracapsular dissection, which involves the removal of the tumor and the parenchyma area of the normal parotid gland, preserving the nerve function, thus minimizing the incidence of facial nerve damage and Frey syndrome/ sweating [11]. The main complication of adenoma excision is related to its location, often in the parotid gland, which can lead to temporary or permanent paralysis of the facial nerve, compromising the patient's quality of life. An additional complication of surgical approaches in recurrent tumors is the development of parotid cancer. Replacement of simple tumor enucleation by other surgical approaches such as superficial parotidectomy, total parotidectomy, and extracapsular dissection as a treatment of choice drastically reduced the incidence of recurrence and tumor complications [12]. Surgical excision is the treatment of choice, although the type of surgery remains a source of debate. Surgical approaches advocated in the literature depend on their location. In parotid gland adenomas the accesses include surgical skin incision where tumour is directly covered and its removal, intraoral excision with or without facial nerve monitoring, Risdon incision, standard incision with a minimally invasive approach for assisted endoscopic resection with preauricular incision [13]. Preoperative detailed imaging for surgical planning is critical. Consulting an oncologist regarding benefits of radiotherapy is potentially beneficial, since postoperative radiotherapy controls the presence of disease residues. In certain cases the tumor is unresectable and treatments are performed in order to improve patient's quality of life and symptoms [14]. The pleomorphic adenoma is a benign salivary gland tumor, composed of ductal proliferation and myoepithelial elements in a myxoid stromal that may vary to chondroid stroma, being able to demonstrate an infinite number of architectural configurations [15]. Histologically, adenoma presents cell proliferation with epithelial differentiation, being morphologically cuboid or basaloid, arranged in sheets, cords and ductiform structures. Peripheral portion of these structures is composed by myoepithelial differentiated cells that constitute myxoid, hyaline and chondroid areas. Myoepithelial-differentiated cells present with fusiform and plasmacytoid morphology and, when located in ducts peripheral areas, they exhibit clear cytoplasm. The tumor presents thickness-variable area, with projections of neoplastic cells [16]. It is also observed that a benign neoplasm reveals a mixture of salivary glands epithelia [10]. Pleomorphic adenomas exhibit membranous and cytoplasmic immunostaining and nuclear staining. The immunohistochemical study suggests different degrees of myoepithelial cells differentiation [17].

\section{CASE DESCRIPTION}

Female, melanodermic patient, aged 29 years old, who attended the Maxillofacial Surgery and Traumatology Service of Federal University of Pernambuco complaining of an increased volume in the left submandibular region (Figure 1). The patient reported having undergone surgical excision of pleomorphic adenoma associated with the left parotid gland in 2006 and after 8 years a volume increase in 
the same situs was observed. Clinical examination revealed a well delimited left parotid region lesion, presenting with a firm and painless consistency. In order to provide a complete diagnosis, a cervical ultrasonography was requested. It exhibited a well-delimited multiloculated lesion, with a $10 \mathrm{~cm} \times 4 \mathrm{~cm}$ size (Figure 2). Firstly, the incision of choice was Risdon's (or submandibular incision), followed by myocutaneous flap divination and differentiation of platysma muscle. After blood vessels haemostasis, tumor resection was performed along with the inferior lobe of the left parotid (Figure 3 and 4). The intradermal skin was sutured at separated points and the cutaneous suture was intradermally continuous. The surgical specimen was sent to the laboratory.

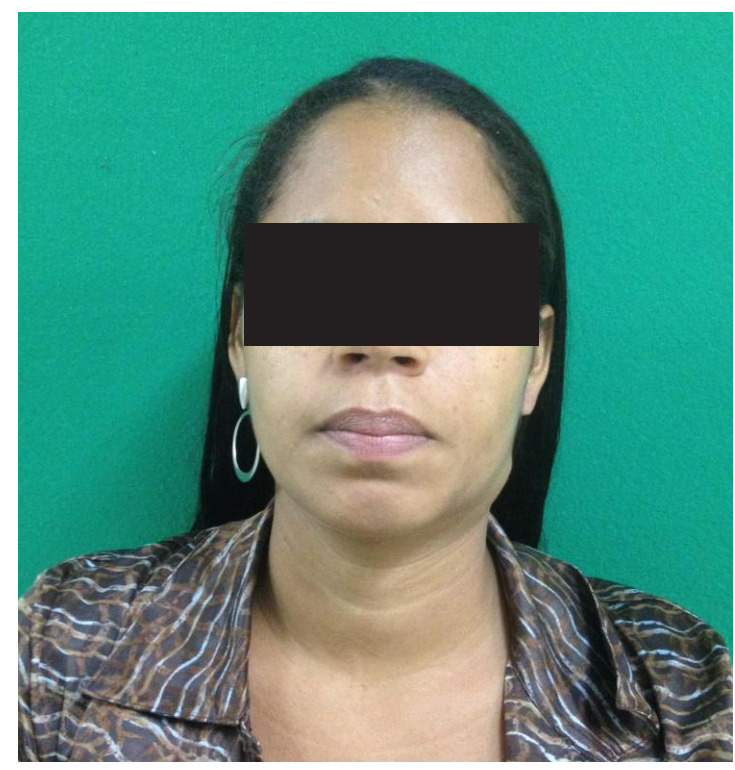

Figure 1. Preoperative - front view.

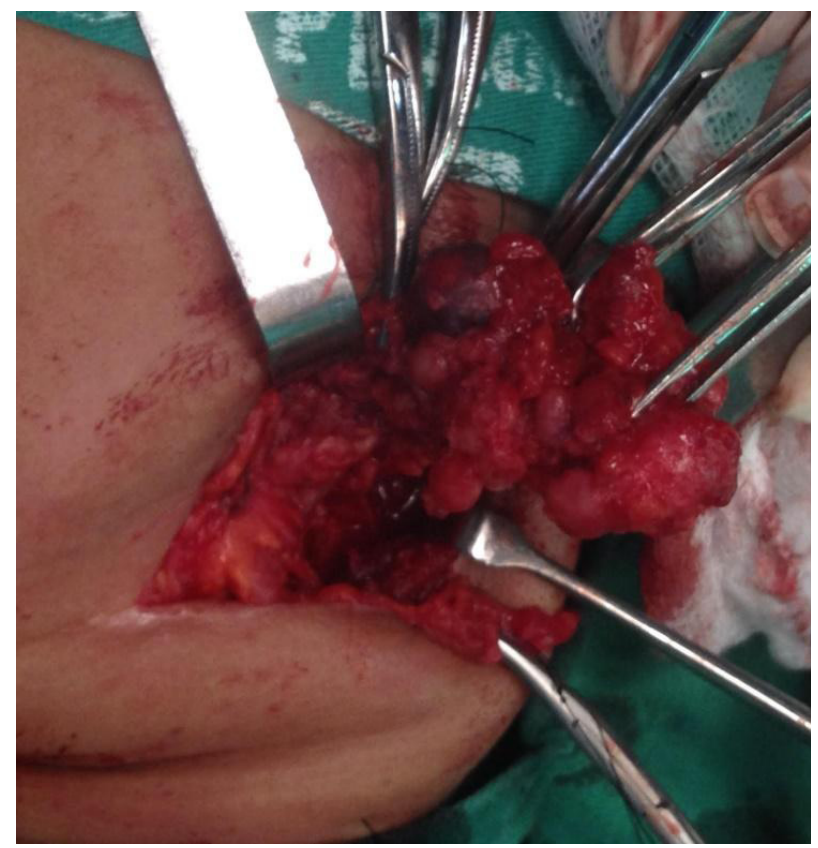

Throughout the postoperative period, the patient remained in the hospital for 5 days and it was prescribed $5 \%$ glycosylated serum, $1500 \mathrm{ml}, 21$ drops $/ \mathrm{min}$, continuous; $0.9 \%$ Sodium Chloride, $1500 \mathrm{ml}, 21 \mathrm{drops} / \mathrm{min}$, continuous; Complex B + Vitamin $\mathrm{C}$ in serum, 01 ampoule in each phase; Cefalotin $1 \mathrm{~g}, 01$ ampoule intravenouslyadministrated every 06 hours; Dexamethasone $4 \mathrm{mg}$, 01 ampoule intravenously-administrated every 06 hours $(2.5 \mathrm{ml}=10 \mathrm{mg})$; Metacloplamide $10 \mathrm{mg}, 01$ ampoule intravenously-administrated every 06 hours in case of nausea or vomiting; Codeine Phosphate + Paracetamol $30 \mathrm{mg}$, 01 oral-administrated table every 8 hours; Cryotherapy and continuous thermotherapy.

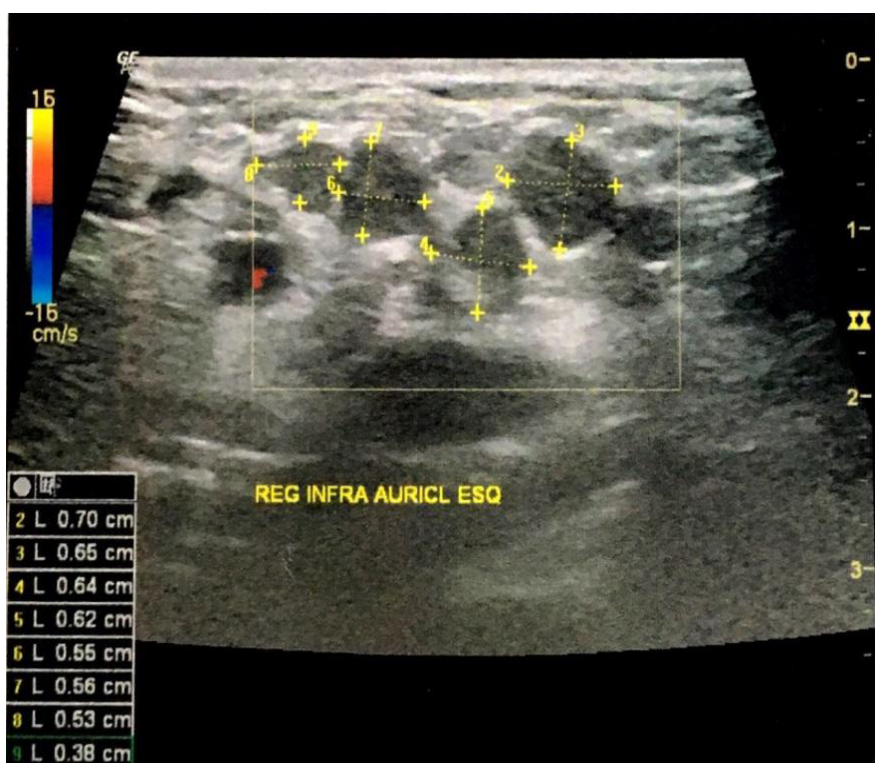

Figure 2. Ultrasonography of the left submandibular region.

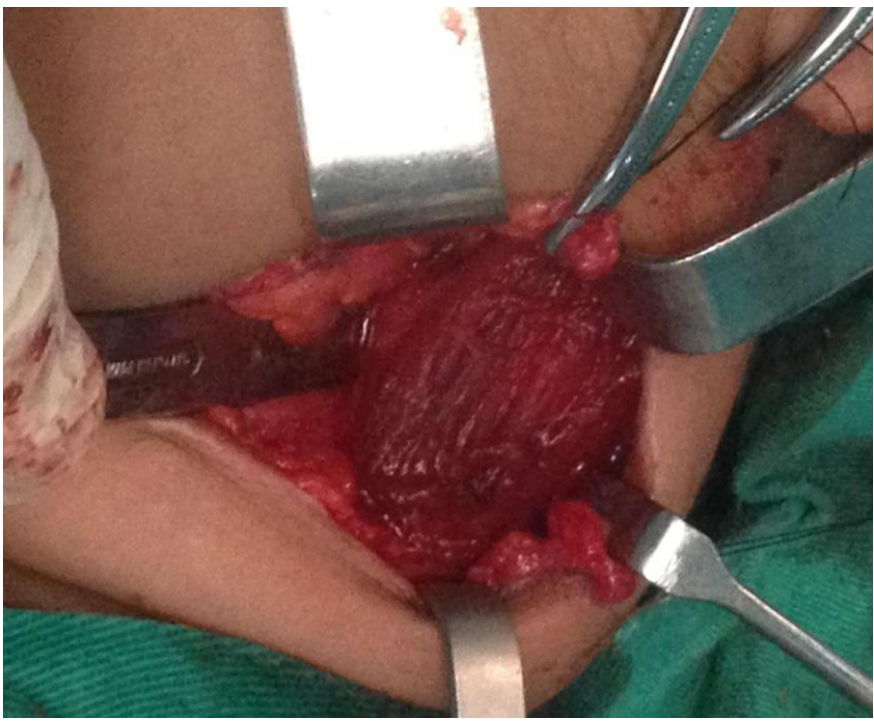

Figure 3 and 4. Differentiation of platysma muscle and tumor resection was performed along with the inferior lobe of the left parotid. 
The surgical specimen submitted to the service of patology of the Clinical Hospital of Federal University of Pernambuco, histologically presents cell proliferation with epithelial differentiation, being morphologically cuboid or basaloid, arranged in sheets, cords and ductiform structures. Peripheral portion of these structures is composed by myoepithelial differentiated cells that constitute myxoid, hyaline and chondroid areas. Myoepithelial-differentiated cells present with fusiform and plasmacytoid morphology and, when located in ducts peripheral areas, they exhibit clear cytoplasm (Figure 5).

We observed the absence of postoperative complications, and the suture removal was performed after 7 days, and patient's follow-up occurred at $30^{\text {th }}, 60^{\text {th }}, 90^{\text {th }}$ and $180^{\text {th }}$ days till the present day (Figure 6).

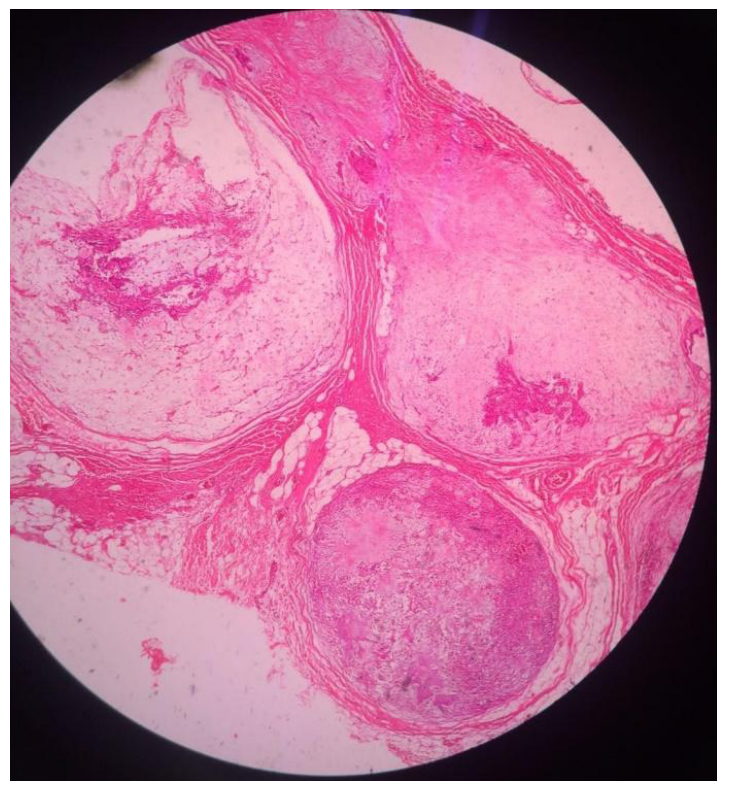

Figure 5. Encapsulated pleomorphic adenoma occupying the parotid gland (HE 1X10).

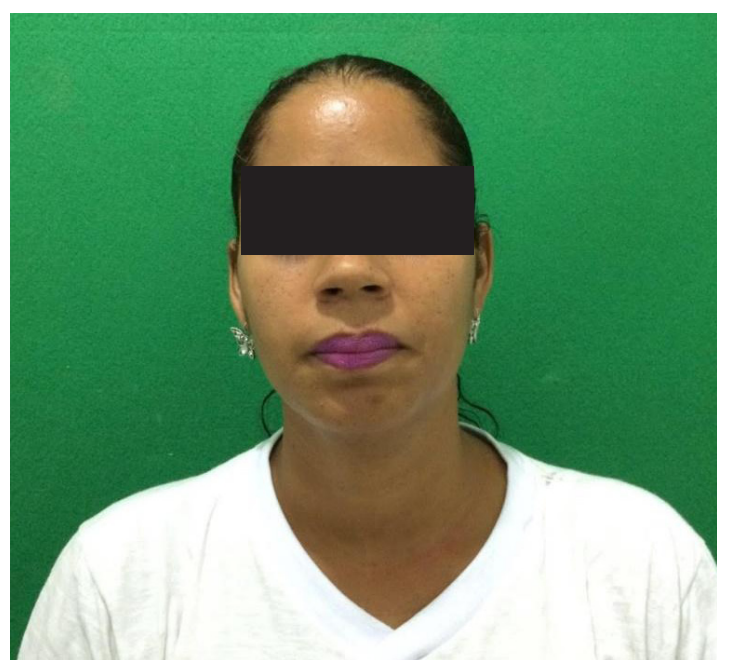

Figure 6. Post-operative 2-year-front view.

\section{DISCUSSION}

According to Nascimento; Vilela, (2014) [2] the pleomorphic adenoma is the tumor that has a considerable prevalence in the major salivary glands, being parotid gland the most affected one. Studies performed by Robertson et al. (2014) [1], revealed a high incidence of pleomorphic adenoma in the parotid gland. The clinical case reported in the present study was an adenoma based in the parotid gland, corroborating with the prevalence described by previous studies.

Among the common clinical features of pleomorphic adenoma described by Maahs et al. (2015) [4], slow and painless growth; solid and palpable capped mass, showing mobility, except when it is located in the hard palate region can be mentioned. The present case report was in accordance with such clinical characteristics.

Regarding the most affected age group Queiroz et al. (2014) [3], people aged between 40 and 60 years old are mostly affected, without ruling out the onset in another decade of life. The patient the present study is not included in the abovementioned age group, however the author did not discard other life periods for the benign mixed tumor onset.

According to Knight; Ratnasingham, (2015) [7] and Lombardi et al. (2014) [6], malignancy may arise in three forms. Although $95 \%$ of pleomorphic adenomas are benign, a small fraction, may demonstrate aggressive onset such as pleomorphic ex-adenoma carcinoma. The patient the present study showed no signs of malignancy.

Kwan et al. (2015) [14] and Jayaram; Patel; Santhanam, (2015) [8] affirms the necessity of preoperative detailed imaging for surgical planning is critical mainly in cases the tumor is unresectable and treatments are performed in order to improve patient's quality of life and symptoms. As the patient didn't show signs of malignancy and all lesions were removed, the patient wasn't referred to radiotherapy.

Smaller salivary gland tumors Jain et al. (2015) [5] signs and symptoms may vary according to their diverse localities, from painless edema and, when located in the nasopharynx or nasal cavity, their infiltration may cause facial pain, nasal obstruction or bleeding. In the case reported the lesion was in the parotid gland, greatest salivary gland, with firm and painless consistency.

The chosen imaging exam was the gland ultrasonography and the histopathological examination through biopsy, as recommended by Witt et al. (2015) [9], who also mention other complementary exams as magnetic resonance imaging.

Through histopathological examination a deposit of myxoid substance was found, with occasional cohesive groupings consisting of ductal epithelial cells and several myoepithelial cells Prado et al. (2014) [17], Werner; Castle (2014) [15], Hughes; Yang; Vargas, (2015) [10] and Tsegga; Britt; Ellwanger (2015) [16] describe similar structures. The histopathological examination of the reported case corroborated with the abovementioned aspects. 
According to Newberry; Kaufmann; Miller, (2014) [13] the technique choice for the pleomorphic adenoma treatment may vary, depending on the location, size, depth and volume of the lesion. Hughes; Yang; Vargas, (2015) [10], and Guerra et al. (2014) [12] describe techniques that preserve facial nerve and its ramifications, aiming to remove the capsule that involves the lesion, or minimally expose the main trunk of the facial nerve. The technique described by Cristofaro et al. (2014) [11] was the chosen one, which consists of surgical excision with safety margin, with whole capsule enucleation and partial parotidectomy, preserving the facial nerve.

\section{CONCLUSION}

Pleomorphic adenoma is a benign tumor with diverse characteristics. The surgical technique choice depends on the depth of the lesion, its extension and its relation with the facial nerve, in order to not cause any damage to the patient, such as transient or permanent injury of the seventh cranial nerve pair, Frey's syndrome and lesion recurrence. Partial parotidectomy was chosen because of the advantages of less exposing the main trunk of the facial nerve including less parotid tissue.

\section{REFERENCES}

1. Robertson BF et al. Pleomorphic adenomas: Post-operative radiotherapy is unnecessary following primary incomplete excision: A retrospective review. Journal of Plastic, Reconstructive \& Aesthetic Surgery 2014;67:e297-e302. https://doi.org/10.1016/j.bjps.2014.09.030

2. Nascimento LA, Vilela TGP. Pleomorphic Adenoma of the Tongue Base: Case Report and Review. Int. Arch. Otorhinolaryngol 2014;18: 328-31.

3. Queiroz CS et al. An unusual pleomorphic adenoma. RGO, Rev Gaúch Odontol 2014;62:319-24.

4. Maahs GS et al. Parotid gland tumors: a retrospective study of 154 patients. Brazilian Journal of Otorhinolaryngology 2015;81:301-6. https:// doi.org/10.1016/j.bjorl.2015.03.007
5. Jain S et al. Pleomorphic adenoma of the parotid gland: Report of a case with review of literature. Ethiopian Journal of Health Sciences 2015;25: 189-94. https://doi.org/10.4314/ejhs.v25i2.13

6. Lombardi M et al. Schwannoma-like pleomorphic adenoma: a case report with review of the literature. Head and Neck Pathology 2014;178-81. https://doi.org/10.1007/s12105-013-0473-9

7. Knight J, Ratnasingham K. Metastasing pleomorphic adenoma Systematic review. International Journal of Surgery 2015;19: 137-45. https://doi.org/10.1016/j.ijsu.2015.04.084

8. Jayaram R, Patel D, Santhanam V. Benign pleomorphic adenoma of minor salivary gland showing perineural invasion: a rare entity. British Journal of Oral and Maxillofacial Surgery 2015;53:81-2. https://doi.org/10.1016/j. bjoms.2014.09.010

9. Witt $\mathrm{RL}$ et al. Etiology and management of recurrent parotid pleomorphic adenoma. The Laryngoscope 2015;125:888-93. https://doi.org/10.1002/ lary. 24964

10. Hughes AL, Yang E, Vargas SO. A Pediatric Soft Palate Mass. JAMA Otolaryngology-Head \& Neck Surgery 2015;141: 391-2. https://doi. org/10.1001/jamaoto.2014.3722

11. Cristofaro MG et al. Pleomorphic Adenoma of the Parotid: Extracapsular Dissection Compared with Superficial Parotidectomy - A 10-Year Retrospective Cohort Study. The Scientific World Journal 2014. https:// doi.org/10.1155/2014/564053

12. Guerra GD, Montagnani S, Tafuri D, Salzano FA, Rocca A, Motta G. Surgical management of pleomorphic adenoma of parotid gland in elderly patients: Role of morphological features. International Journal of Surgery 2014. https://doi.org/10.1016/j.ijsu.2014.08.391

13. Newberry TR, Kaufmann CR, Miller FR. Review of accessory parotid gland tumors: pathologic incidence and surgical management. American Journal of Otolaryngology 2014;48-52. https://doi.org/10.1016/j. amjoto.2013.08.018

14. Kuwan EC et al. Sinonasal and skull base pleomorphic adenoma: a case series and literature review. In: International Forum of Allergy \& Rhinology 2015; 460-8. https://doi.org/10.1002/alr.21500

15. Werner RL, Castle JT. Recurrent Pleomorphic Adenoma. Head and Neck Pathology 2014;303-6. https://doi.org/10.1007/s12105-0130504-6

16. Tsegga TM, Britt JD, Ellwanger AR. Pleomorphic Adenoma of the Accessory Parotid Gland: Case Report and Reappraisal of Intraoral Extracapsular Dissection for Management. Journal of Oral and Maxillofacial Surgery 2015;73:564-70. https://doi.org/10.1016/j.joms.2014.09.015

17. Prado RF et al. Pleomorphic Adenoma versus Basal Cell Adenoma: An immunohistochemical analysis with b-catenin. Brazilian Dental Science 2014. https://doi.org/10.14295/bds.2014.v17i1.944 